\title{
Developing Research Tool Of Religious Moderation: Learning From Islam
}

\author{
Deva Alvina br Sebayang ${ }^{1}$, R. Adang Nofandi ${ }^{2}$ \\ \{dee_bayanc@yahoo.co.id ${ }^{1}$, adangnof@gmail.com ${ }^{2}$ \}
}

Peneliti Balitbang Kemenag RI ${ }^{1,2}$

\begin{abstract}
Research on religious moderation has been popular since the discourse included in RPJM Indonesia 2021-2024. Differences in theological and religious practices that sometimes collide, have colored the dynamics of socio-religious in the context of diversity in Indonesia. Moreover, recently, the sharpening of segregation between different groups has led the discourse of religious moderation as the priority program of Regious Affairs under the tenure of LHS. Based on literature reviews of several existing studies, it is very important to build the research tools on religious moderation. This study aims to develop research tools on religious moderation. This study using qualitative research methodology in Islamic communities in the context of both internal and external diversity. The research conducted in Lasem Village which is known as a tolerant city, and at the same time is popular as center for Islamic boarding schools as well as Small China Town. Since the research locus is still limited on Islam, for more general purposes, this paper suggests the need for further studies on other religions.
\end{abstract}

Keywords: Diversity, Religious Moderation, Research Tools, Islam, Lasem.

\section{The Problem of Religious Moderation Research}

In 2019, at the end of the tenure of the Indonesian Minister of Religion, Lukman Hakim Saifuddin (LHS) (2014-2019), the Religious Affair released the book of Religious Moderation. Since the beginning of his tenure, LHS has set religious moderation as a priority for the performance of the Religious Affair. Religious moderation has even become one of the important issues in the National Medium-Term Development Plan (RPJMN) 2020-2024. Slamet Soedarsono, the Deputy of Bappenas' Political, Legal, Defense, and Security, stated that religious moderation is one of important issues in the National Medium Term Development Plan (RPJMN) 2020-2024. However, there are two major issues with the religious moderation program and its implementation in the hypothesis of this study. First, there is a paradigm where religious moderation programs are attached to deradicalisation efforts, where moderation is defined as neither extreme nor radical. And when talking about deradicalization or fighting extremism, it is often understood narrowly as religious extremism and leads to Islam (Nasir, 2019). Second, there have not been studies related to religious moderation research instruments.

First, LHS and the team were aware of such perspective he asserted "religious moderation"(moderasi beragama) instead of "moderation of religions"(moderasi agama). In 
the beginning of the book, "Moderasi Beragama", the authors explain that the reason for the importance of religious moderation is the diversity of Indonesia (Moderasi Beragama, 2019, p.10). Furthermore, the authors state that there is a misunderstanding on the religious moderation program (Moderasi Beragama, 2019, p.12). This perspective is also driven by the religious context in Indonesia which has recently been heating up politically. As admitted by Haedar Nasir, "by the provocations of the elites, many citizens are worried about the condition of the nation which is starting to drift apart these days." Iqbal, a lecturer at Center for Religious and Cross Cultural Studies Gadjah Mada university and an expert on conflict resolution and peace studies, revealed that political actors had recently used religious and cultural symbols in elections. So that the condition of the nation context where the religious moderation program was initiated causes it to be quite attached to deradicalization.

Besides the political context, the definition of moderation derives from English: "The avoidance of excess or extremes, especially in one's behaviour or political opinions." Based on this definition, Moderation is a rejection of extremism. Thus, it is undeniable that religious moderation attach to deradicalization or efforts to reduce extremism.

There is a book that about moderation in French politics that explains that although the virtue of politics is moderation, yet must be vigilant with the term.

While those engaged in writing the history of complex concepts such as moderation are inevitably bound to appear old-fashioned given their focus on reading and interpreting texts, they must also go beyond studying the language in which these notions are expressed. since moderation has always been used with various intents and meanings, one must carefully examine the contexts in which it has been employed and the various functions and purposes it has served. such complex concepts are never used in isolation but always in ideological constellations that constitute entire belief systems. This is all the more true of a complex and elusive concept such as moderation, which, as one historian pointed out, is unlike other classical concepts such as general will, sovereignty, or reason of state (Craiutu , Aurelian, 2012, p.6).

According to this book, moderation is a complex concept and requires contextual interpretation. Therefore, we must be vigilant with the purpose of utilizing the term.

The second urgent issue is that when religious moderation has been successfully included as an important issue of the 2020-2024 RPJMN, there has not been found proper research tools on several studies that had been carried out. Research tools in this study means research instruments, as well as the framework that underlies it, how to examine religious moderation in society? How to read religious moderation? This is important because the research tools can be developed into a religious moderation "development tools". The author team of Religious Moderation Book, that published by the Religious Affairs, propose four indicators to measure religious moderation. Namely, nationality engagement, empathy, nonviolence, and local wisdom. Yet, how to construct research instruments to read religious moderation?

The ways they become research instruments: (1) nationality commitment. How do we measure nationality commitment ot the society? (2) Tolerance. How do we measure it? Is it measured by internal or external tolerance? (3) Local culture. How is the relation between religious moderation and local culture, how to measure the acceptance of local culture? (4) Non-violence, how to describe moderation related to non-violence. How to read religious moderation, in this research is called research tools. It is illustrated like a microscope to see animals, so it is necessary to build a socio-religious "microscope" to see religious moderation. 


\section{Research Questions}

1. How to conduct research on religious moderation? How to build research instruments on religious moderation?

2. What is the proper definition of religious moderation in the context of diverse society?

\section{Literature Review}

From several articles discussing religious moderation, it tends to focus only to Islamic moderation. In addition, there are several articles that exmine religious moderation, mostly are literature studies, and only few is qualitative research. From those several studies I select two studies that are more directed towards religious moderation and examined by using qualitative research.

\begin{tabular}{|c|c|c|c|c|}
\hline Year & Research & $\begin{array}{l}\text { Definition of } \\
\text { Moderation }\end{array}$ & $\begin{array}{l}\text { Research } \\
\text { Questions }\end{array}$ & Method \\
\hline $\begin{array}{l}\text { 1June } \\
2019\end{array}$ & $\begin{array}{l}\text { Religious Moderation } \\
\text { for Muslim Minorities } \\
\text { of Chinese ethnicity in } \\
\text { Makassar City } \\
\text { Ramli, Parepare State } \\
\text { Islamic Institute }\end{array}$ & $\begin{array}{l}\text { Religious } \\
\text { moderation is a } \\
\text { moderate view of } \\
\text { diversity as a way } \\
\text { to accommodate } \\
\text { the diversity of } \\
\text { religions in } \\
\text { Indonesia. } \\
\text { (Busyro, Aditya } \\
\text { \& Adlan, 2019) } \\
\text { Islam }\end{array}$ & $\begin{array}{l}\text { How is religious } \\
\text { moderation for } \\
\text { Muslim } \\
\text { minorities in } \\
\text { Makassar City? } \\
\text { Some of the } \\
\text { research } \\
\text { questions are as } \\
\text { follows: How is } \\
\text { the religious and } \\
\text { cultural diversity } \\
\text { of Chinese in } \\
\text { Makassar City? } \\
\text { How is the } \\
\text { religious } \\
\text { moderation of } \\
\text { Chinese Muslim } \\
\text { in Makassar } \\
\text { City? What are } \\
\text { the opportunities } \\
\text { and challenges } \\
\text { of diversity for } \\
\text { the Chinese } \\
\text { Muslim minority } \\
\text { in Makassar } \\
\text { City? }\end{array}$ & $\begin{array}{l}\text { The research } \\
\text { location and } \\
\text { object were on } \\
\text { diversity for the } \\
\text { Chinese Muslim } \\
\text { Ethnic Minority } \\
\text { in Makassar City } \\
\text { using qualitative } \\
\text { descriptive. The } \\
\text { data were } \\
\text { obtained from } \\
\text { religious figures, } \\
\text { including } \\
\text { Muslims scholars } \\
\text { from academia, } \\
\text { among the } \\
\text { administrators of } \\
\text { Islamic social } \\
\text { organizations } \\
\text { (ORMAS), the } \\
\text { Chinese Muslim } \\
\text { community. } \\
\text { Besides, } \\
\text { secondary data } \\
\text { was in the form } \\
\text { of documents, } \\
\text { archives, several } \\
\text { events that have } \\
\text { occurred, and the } \\
\text { condition of the } \\
\text { Muslims. }\end{array}$ \\
\hline
\end{tabular}




\begin{tabular}{|c|c|c|c|c|}
\hline 2020 & $\begin{array}{l}\text { The model of religious } \\
\text { moderation based on } \\
\text { the Salaf Islamic } \\
\text { Boarding School. } \\
\text { Ali Nurdin, Maulidatus } \\
\text { Syahrotin } \\
\text { Journal of Islamica }\end{array}$ & $\begin{array}{l}\text { This research was } \\
\text { conducted based } \\
\text { on the } \\
\text { assumption that } \\
\text { pesantren-based } \\
\text { religious } \\
\text { moderation is } \\
\text { perceived as an } \\
\text { effort of the } \\
\text { Islamic boarding } \\
\text { school to instill } \\
\text { moderate Islamic } \\
\text { values in Islamic } \\
\text { boarding school } \\
\text { students and } \\
\text { society, namely a } \\
\text { balance } \\
\text { understanding of } \\
\text { logical and } \\
\text { realistic thinking } \\
\text { and refers to } \\
\text { various } \\
\text { comprehensive } \\
\text { and consistent } \\
\text { sources. }\end{array}$ & $\begin{array}{l}\text { This study aims } \\
\text { to understand } \\
\text { and describe the } \\
\text { model of } \\
\text { religious } \\
\text { moderation } \\
\text { developed and } \\
\text { implemented by } \\
\text { the Al-Anwar } \\
\text { Sarang Islamic } \\
\text { Boarding } \\
\text { School, } \\
\text { Rembang, } \\
\text { Central Java. }\end{array}$ & $\begin{array}{l}\text { This type of } \\
\text { descriptive- } \\
\text { qualitative } \\
\text { research is used } \\
\text { to examine and } \\
\text { provide } \\
\text { interpretation } \\
\text { according to the } \\
\text { context of the } \\
\text { development of } \\
\text { religious } \\
\text { moderation in } \\
\text { Islamic boarding } \\
\text { schools. }\end{array}$ \\
\hline
\end{tabular}

Both of these studies have not described the research instrument based on the definition of moderation itself. This is understandable because the discourse on religious moderation has just added into a national program in 2019, and the book on religious moderation also published in 2019.

\section{Research Methodology 4.1. Data Collection Method}

Since this study is relatively new and is intended to develop research instruments, the data collection was done using qualitative method. The research was carried out in 2019 when the Center for Research and Development of Bimas for Religion and Religious Services conducted research on the theme of religious moderation. The research location is in Lasem Rembang, Central Java, because in 2015 I had visited this area and seen good interfaith relations. Before the field study, a theoretical framework and research instruments had been prepared, and that was opened to field data. The data obtained through observations, in-depth interviews with several stakeholders and the people of Lasem Rembang, Central Java. The informants included several groups such as religious leaders, community leaders, the police chief, regional officials, students of Islamic boarding school, batik makers, batik entrepreneurs, as well as some ordinary people in Lasem. 


\subsection{Theoretical Framework Religious Moderation}

Terminology of Moderation according to KBBI: (1) reduction of violence; (2) avoidance of extremism. While meaning of the term in English according to Oxford Advanced Learners Dictionary: "Moderation is the quality of being moderate; freedom from excessive; restraint."

In Greek history, moderation:

is also a principle of life. In ancient Greece, the temple of Apollo at Delphi bore the inscription Meden Agan ( $\mu \eta \delta \grave{\varepsilon} v$ ö $\gamma \alpha \nu$ ) - 'Nothing in excess'. Doing something "in moderation" means not doing it excessively. For instance, someone who moderates their food consumption tries to eat all food groups, but limits their intake of those that may cause deleterious effects to harmless levels (Shapin, 2010, p.245)

Based on the Greek history, "moderation" is a word derived from the Temple of Apollo referring to freedom from any act of exaggeration or restraint. A person who used to eat food in moderation, trying to eat all kinds of food. This changing dietary can cause the damaging effects to harmless levels.

Referring to these three languages, Indonesian, English and Greek, Moderation is closely related to the action of opposition towards exaggeration which is now known as extreme.

Another term that has close meaning to moderation is "Wasatiyah" from the Islamic tradition. This term is taken from Surah al-Baqarah [2]:143, "And thus We have made you a wasathan ummatan so that you are martyred for humans and for the Prophet (Muhammad) to be martyred for you." "Wasat" or "wasatiyyah (وسطية)" is a word derived from Arabic which means good, middle, fair, balanced. Referring to its meaning of the "middle way" or "moderation", it is a balanced path that rejecting extremist (Kamali, 2015).

What definition is utilized by the Religious Ministry? For them, religious moderation refers to the attitude of reducing violence and avoiding extremism in religious practice. Religious moderation can be perceived as a perspective. Furthermore, it is an attitude or behavior which always takes a middle position, always acts fairly and is not extreme in terms of religion (Puslitbang Kemenag RI, 2019, p.17).

The discourse of moderation is still debated among scholars. Kamali has warned that the significance of meaning of the word "Wasatiyyah" needs to be renewed to be closer to diversity, instead of merely whether it is right or left extremist,, or whether it is conventional or liberal, as stated by Nasir. In his book, Kamali referring to Al Imam As-Shafi'I:

Moderation is the heart, moderation is the way. Kamali refers to the need for moderation as we consider diversity from within (ikhtiläf), a kind of reasoned disagreement and the need to acknowledge that we might be right and "the other" might be wrong, but that the other way could be possible, too, as al-Imam ash-Shafi'i stated. The need for wasatiyyah has acquired renewed significance in the pluralist societies of our time, especially in light of Huntington's thesis on "clash of civilizations" and the aftermath of the September 2001 terrorist attacks. Restoring balance to many of the disturbing realities of our time has become a pressing calling of the world community and the ummah. he call to moderation that we advocate is addressed to the followers of all religious and cultural traditions and communities (3 (Kamali, 2015).

The argument in that research identifies religious moderation as whether it is extreme or liberal, but in the context of a homogeneous society. This means that for one teaching or practice there is a question whether it will become liberal or extreme towards other teachings. However, it does not suitable for the diverse Indonesian context. The main thing is not 
choosing to be an extremist or a liberal. In the Indonesian context, moderation is confronted with religious diversity in terms of dogmatic/religious teachings and diverse life practices that for some extend even clash each other. For instance, residents in region A are composed of various religions, how can residents make an agreement about Pig farming or market? In the context of diversity, how to avoid violating the rights of any religious group and its practices, while at the same time, not violating the implementation of any religious teachings of other religious groups. Therefore, the definition of religious moderation, in this research, is a middle way that created to bridge the diversity of religious practices and teachings, based on the principles of justice and equality/balance.

\section{How to build research tools (instruments) of religious moderation?}

Based on the book "Religious Moderation", the indicators of religious moderation are: 1) national commitment, 2) tolerance, 3) non-violence, and 4) accomodative towards local culture. These have been helping in understanding religious moderation, can be utilized as a basis for building research questions, yet it has not become a research tool / instrument. While the previous researches focus only on how the relationship between religion A and religion B, and also about how the Islamic Moderation Teachings in pesantren.

From the definition, religious moderation is related to interreligious dialogue because dialogue has a definition of "a two-way communication between persons who hold significantly differing views on a subject, with the purpose of learning more truth about the subject from the other." It is precisely similar to the previous example, where religious moderation in Indonesia is in a context of diversity. How to reconcile different religious practices and teachings that are considered to be flawless, even though they are contradictory? This is the key question of religious moderation, including in interreligious dialogue studies.

According to Leonard Swidler, an expert on Inter-religious Dialogue Studies, there are three significant challenges in building inter-religious dialogue, namely truth claims, conflict history, and prejudice on the identity of each group. (1) How is the prejudice about other religions? (2) How to accept the truth claims of other religions, while at the same time having their own religious truth claims? (3) How they deal with conflicts, and how to overcome them?

\section{Results and Findings}

5.1. Islam in Encountering the External Diversity of Religions and Tribes in Lasem Village

Lasem is known as the Santri city. Lasem has a long history of Islamic boarding school (pesantren) practice, and it is recognized that it was initiated by Sunan Bonang. There are 27 Islamic boarding schools in this area, and many of the students, santriwan and santriwati, are from other areas around it. The total number of people was 50,011 people, with details based on data from the Lasem District Religious Affairs Office in 2018: 53,172 Muslims, 1616 Christians, 892 Catholics, 22 Hindus, 207 Buddhists, 44 Confucians (Kua Lasem, 2018).

Lasem is a sub-district of Rembang Regency. Located on the North Coast of Java Island, it is consists of villages with coastal and mountains area, as well as beaches. The territorial boundaries are as follows: In the western is bordered with Rembang sub-district, in the eastern is Sluke sub-district, in the northern is the Java Sea, in the southern is Pancur district Rembang. Lasem sub-district is divided into 20 villages, namely Karasgede, Jolotundo, Sendangcoyo, Ngargomulyo, Kajar, Selopuro, Sumbergirang, Karangturi, Babagan, Dorokandang, Gedingmulyo, Soditan, Ngemplak, Sendangsri, Gowak, Sriombo, Binangun, 
Bonang, Tasiksono and Dasun. Although it is officially part of the Rembang Regency, historically, Lasem city is older than the Rembang area. By referring to various sources, M Akrom, in the book "Lasem Negeri Dampoawan", concludes that Lasem already existed and became an essential area of the Majapahit Kingdom (Unjiya, 2015: 24).

\section{The History of Social Cohesion and Its Preservation a. Sunan Bonang, the Cornerstone of Moderation in Lasem}

The history of Lasem village cannot be separated from Sunan Bonang. Leaders of all religions, and even the lay people there always speaks about the existence of Sunan Bonang. H.M. Zaim Ahmad Ma'shoem, the supervisor of the Kauman Islamic Boarding School, popularly known as Gus Zaim, stated that the practice of hospitality tradition toward other ethnic and religious groups that always by Islamic leaders in Lasem was taught by Sunan Bonang. The style of Islam in Lasem is strongly influenced by the Islam taught by Sunan Bonang.

Sunan Bonang is the son of Sunan Ampel and Nyai Ageng Manila, who was born in 1465, under the name Raden Maulana Makdum Ibrahim. H Abdul Wachid (60), an administrator of the Sunan Bonang Foundation, in Bonang Village, Lasem sub-district, told that Maulana Makdum Ibrahim was commanded by his teacher to meditate and fast when he arrived in the western area. He wandered and walked westward and found a lush Kemuning tree. After arriving at a place, on the slopes of the Argopuro mountains on the north coast, he finally found a lot of Kemuning trees. Known as Bonang Village, Raden Maulanan Makdum Ibrahim eventually became popular with the name "Sunan Bonang". Bonang Village is the center for Islamic boarding schools to carry out the spread of Islam.

An important note from Syiar Sunan Bonang, is that the Sunan came to the people who had not known about Islam, using social approach. Sunan always visited and lived with the residents. By doing so, the people began to be closer and follow his ways of life and his teachings. One day Sunan built a mosque which was said to be built only in one night, and the residents were surprised to see Omah Gede in the middle of the forest. Sunan Bonang did not force the residents to enter the mosque and embrace Islam. But his good character and his approach in spreading Islam through Javanese culture, eventually caused many people to follow him knew the Omah Gede as a mosque. The mosque, which was built in the 15 th century, is named Makdum Ibrahin Sunan Bonang and is located in Bonang village, not far from his tomb in Lasem, Rembang Regency. The mosque is not merely become House of Worship for muslims, but also a place for community discussion, as was done by Sunan Bonang. The popularity of Sunan Bonang as a Kyai was spread out to other regions, and caused Sultan Mahmud from Minangkabau, and his family, became the disciples of Sunan Bonang. After Sultan Mahmud looked for a Kyai to translate a book that was inherited from the King of Minangkabau. Sultan Mahmud, known as Kyai Jejeruk, was buried in Binangun Village, Lasem District. The descendants of Sultan Mahmud continue spreading amiable Islam, in the context of Javanese culture. One of his decendents is the founder of Nahdlatul Ulama, KH Ma'shum, and the current generation, Gus Zaim. 


\section{b. The Kuning (Yellow) War (1740-1743) when the Batavian Rulers Oppressed the Chinese.}

There were a struggle in Lasem that spearheaded by the great ulama, Kyai Baidlawi, along with Oei Ing Kiat and Raden Panji Margono to mobilize the troops of Lasem against the VOC. The Gie Yong Bio Temple is a place of worship for the Tridharma people in Lasem City, Rembang, Central Java. This temple, located in Bagan Village, has a long history of the Kuning (Yellow) War in 1741-1750. There is a statue of Raden Panji Margono, in this temple (see: http://lensapena.id/2019/11/unik-ada-patung-bangsawan-jawa-di-klenteng-gie-yong-biolasem/). A monument of the Struggle of Chinese and Javanese Warriors against the VOC in the Yellow war was built at one of the $\mathrm{Cu}$ An Kiong monasteries. We can also find the same monument at the Chinese Cultural Park, in the Taman Mini Indonesia Indah area.

As a memorial monument on the history of land struggle, a statue of Raden Panji Margono, who is not a Buddhist figure, was built in a Buddhist house of worship. This makes Lasem unique. Why do they do it? According to Pak Gandor, a Chinese cultural observer, the aim of the monument was to maintain the memory of the collective struggle to defend the land of Lasem. Specifically to remind Chinese youth that other ethnicities, especially Javanese, are brothers in arms. Moreover, it also reminds how their ancestors had fought for the land and Indonesian Independence in Lasem Region. The question is, how many Houses of Worship teach Nationalism by telling the historical struggle for the land where the Houses of Worship are located? Does religion only teach about religion without teaching nationalism? This is important since the diversity has existed for centuries and there are many stories about the collective struggle of our heroes.

\subsection{How is the prejudice towards other religions?}

When I ask Lasem people' views on other religions or other ethnicities, I seem to be a strange person who creates their separation. If that happens now, then it is a matter of social cohesion in Indonesia because it widens the distance between them and us (Burhanuddin: 2008). It does not appear in the Chinese-Javanese or Muslim-Buddhist or Christian-Chinese relations. In everyday life they sit and drink coffee together before and after work. This question was finally addressed to the santriwan and santriwati in two Islamic boarding schools, namely the Kauman Islamic Boarding School, H.M. Zaim Ahmad Ma'shoem and Al Hidayat Islamic Boarding School, Soditan Village, Lasem, Rembang Regency, which were supervised by KH Moh Shalahuddin Fatawi. Of the 15 informants, they stated that there was a tendency to feel strange in the early days of living in Lasem. "Why is the pesantren in the middle of a Chinese settlement? Whereas, they are contrary in terms of food and dressing" said a santriwan of the Kauman Islamic Boarding School located in Karangturi village. A santri from the Al Hidayat Islamic Boarding School explain differently, "I have never been friends with Chinese people. I heard from my friend that the Chinese employer is stingy and abusive." Another said, "My house is in a tourist area, several times the Chinese drive recklessly, disrespecting the local people."

All the santri who came from various regions in Indonesia had a bad prejudice against the Chinese, although it is because of other people's experiences or they have never related with Chinese, but they generalize bad actions committed by other an ethnic group. However, after living in a pesantren where the religious leaders have good relations with the Chinese, those views have been changed. When I asked the question, "How did you react when you heard from the social media the cases of Ahok or Meliana or any cases of Chinese dealing with pribumi?" Their answer, "That's their lives not our lives here." Pak Semar as the head of the RT, admits that the Santriwan-Santriwati are very active in relating to local 
residents such, throughs varuious activities such as cleaning the environment, attending grief events or parties, helping to prepare events at Pak RT's house, who are Chinese and Christian, and even attending Chinese celebrations. Pak Semar has considered the santri of the Kauman Islamic Boarding School as his children. That is similar with the Al Hidayat Islamic Boarding School, where Gus Sholahuddin often helds events with young people of other religions, such as planting trees, leadership training in church yards, etc. in the beginning, the Santri were a bit afraid to relate with young people of other religions, but after it was explained and had been prepared according to the Akidah, they get use to it and no longer having any prejudice towards other religions or ethnicities.

\subsection{How to accept the truth claims of other religions, while at the same time having their own religious truth claims?}

According to Gus Zaim, everyone has the desire to convert others to his/her religion. The tendency of majority-minority relations subordination renders traumatic of the past leading the emergence of prejudice. Gus Zaim explained that he took an inclusive approach, with the understanding, which he believes, that all religions worship God and all adherents are human. This is the rationale of him accepting Confucianism and Buddhism as neighbors. Mutual relationship is very necessary in living together. Tolerance and rewards are important. The theological basis for interreligious dialogue approach accoridng to Gus Zaim are:

1. The principle of humanity (being able to feel sick, having needs)

2. The method of Rasulullah SAW "Al Imanu Billah". Faith in Almighty God. Whatever your religion, you have God and practice your religion piously and responsibly.

3. Al Mukminun regarding the benefical or welfare for others. There are 4 beneficials: 1 . Speech 2. Action (Al Amal) 3. Social status, for instance, if there is a minority that be harmed then it must be helped. 4. Economic beneficial.

Based on Gus Zaim's explanation, Religion becomes the transcendental foundation of humans towards humanitarian issues. Religious teaching is a basis for interreligious actions that he practices as a religious figure of the majority.

Rev. Nindya from the Javanese Christian Church, Rev. Immanuel from the Indonesian Christian Church, and a priest of Catholic Church in Lasem acknowledge that there are some joint programs among religious communities. For examples, planting trees, Muslim youths guarding the church at Christmas, program of providing water pump during the dry season, etc. There was a time when muslims community questioning about guarding the church at Christmas, the chairman of MUI in Lasem, KH. Agus Naufal, responded by explaining that they do not need to enter the church, just in the parking area of the church yard.

\section{Local Wisdom}

Jagongan and Ngopi are Javanese cultures that are maintained as a medium for the social cohesion in Lasem. In Jagogan and Ngopi, according to Pak Gandor, pragmatic politics is not allowed. Practical political debate in order to gain the masses by demonizing the opposing party is not allowed in Jagongan. Many social problems are discussed by the leaders while sitting together. Lasem has won a competition in the Indonesian Independence Day by creating a banner with the symbol of the Book and Coffee.

\section{Economic Relation}

Equality in economic relations is very important. Pak Santoso is known as a Batik entrepreneur who cadres the younger generation to become batik entrepreneurs in Lasem. This 
devout Chinese Christian has good relations with Pak Gandor and Gus Zaim. A batik maker who worked for him told that Pak Santoso considers batik makers as entrepreuners not as labors. Pak Santoso gives them batik skills, batik materials, bought written batik from them, gives them THR, daily savings, the opportunity to have loans for business. In terms of religion, Pak Santoso provides a place for his workers to pray by establishing a prayer room in his batik-making building and allowing them to worship on time. According to Pak Santoso, "batik maker is not an object of exploitation for entrepreneurs. Eventhough entrepreneurs have capital and networks but we don't have the skills or time and quality of work like them. So we are both the subject of business actors. I teach this value to my children and the young entrepreneurs." Even in trades, there is always informal communication between buyers and the Chinese sellers.

\section{The Challenge of Moderation in Lasem}

Even though Lasem is known as a tolerant city but it still has dynamics in religious relations, such as in the case of Ahok, the conflict in branding Lasem, preparations for the visiting of the President. Interestingly, some say Lasem is a city of santri, another group enthusiastically declaring Lasem as a city of Little China. Subagio, a Chinese businessman, owner of the Lasem Candu House, stated that Lasem is little China, after the coverage of Nat Geo Indonesia, then there was a businessman declaring the branding too quickly. The branding as litlle China was opposed, because Lasem has a very old Islamic boarding school tradition. There had been formal negotioation at the police and local government offices, but religious leaders and the community immediately resolved the issue by holding informal meetings. They talk about conflicts by building friendship, through Jagongan and Ngopi. Finally they decided that the visiting of the President was not necessary, and Lasem does not need any branding.

\section{Discussion}

\section{What is Religious Moderation? \\ Religious Moderation as A Paradigm of Just and Balance Heart}

A general understanding about religious moderation is position neither right nor left, but in the middle. It can be illustrated as follows (see the figure). If $\mathrm{P}$ is different from $\mathrm{R}$ then $\mathrm{Q}$ chooses in the middle. So $\mathrm{Q}$ has a different position from $\mathrm{P}$ and $\mathrm{R}$ which are not related each other. This is not religious moderation. Religious moderation is not a third position between right and left that are different and unrelated.

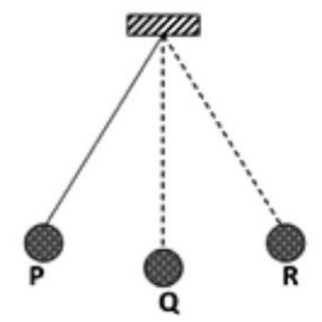

Religious moderation is as shown below. If $\mathrm{A}$ and $\mathrm{C}$ are different, $\mathrm{B}$ builds a relationship between the two, asking and then bridging on the two parties, and deciding on the good for the two parties. This means that between the two differences, religious moderation building a line to bridge the differences. This is not easy, it requires B to be fair and balanced towards $\mathrm{A}$ and 
C. If there is a conflict, B gives space for both parties to reveal stories based on each perspective versions, in making decisions B does not choose the most correct one but bridges the truth of the two. B here is not creating a different and unrelated position, instead take a middle position to bridge. This is the proper illustration.

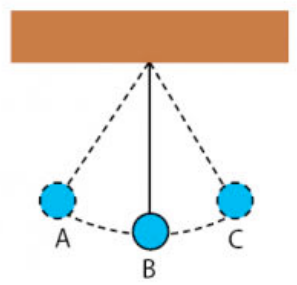

\section{Religious Moderation as a Path of Diversity and Harmony is the Result}

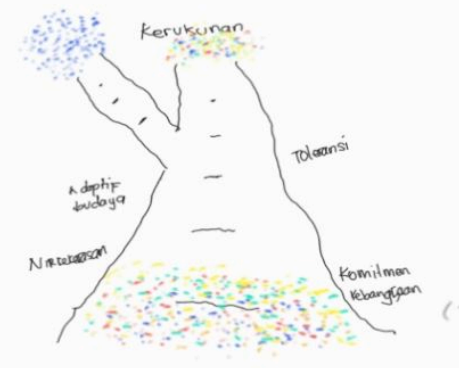

There remains frequent confusion about: "what is religious moderation?" Answer to this question tends to equalize it with the concept of harmony. This study agrees with the concept of moderation proposed by Kamali. In his book Kamali quotes Al Imam As-Shafi'I, Moderation is the heart, moderation is the way. Kamali refers to the need for moderation as we consider diversity from within (ikhtilāf), a kind of reason ed disagreement and the need to acknowledge that we might be right and "the other" might be wrong, but that the other way could be possible, too, as al-Imam ash-Shafi'i stated. The need for wasatiyyah has acquired renewed significance in the pluralist societies of our time (Kamali, 2015).

As shows in the picture, religious moderation is a path that emerges from the colors diversity. The ultimate goal of the path is to preserve the diversity of colors. Moderation is not harmony. Harmony is the result of an action / process / system / path. The result contains conditions of harmony even though the reality of diversity contains friction. Islam is a world religion that contains diversity, why does Islam survive until today? This indicates that there is a system so that its existence as a world religion remains, and at the same time maintaining its diversity (Mir Kasimov, 2014). Islam recognizes the term "Wasatiyyah", a path that produces harmony, that what religious moderation. 


\section{How to Conduct a Research on Religious Moderation?}

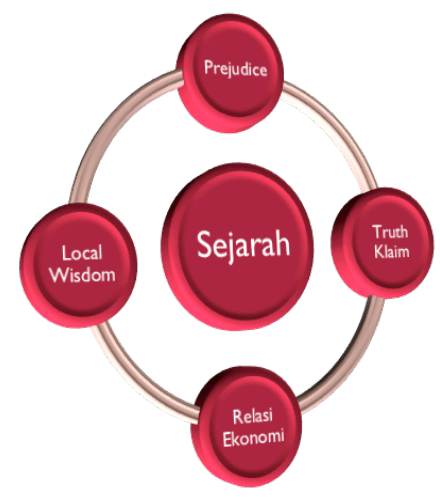

There are 5 variables or entry points to study religious moderation

\begin{tabular}{|c|c|c|c|}
\hline No & Variable & Questions & $\begin{array}{l}\text { Indicator of } \\
\text { Religious } \\
\text { Moderation }\end{array}$ \\
\hline 1 & $\begin{array}{l}\text { History of } \\
\text { Social Cohesion }\end{array}$ & $\begin{array}{l}\text { What is the social cohesion history of } \\
\text { community? } \\
\text { Is there any historical momentum underlying the } \\
\text { bonds of community unity? Such as a collective } \\
\text { struggle for the land of people and } \\
\text { independence? } \\
\text { Are there any historical figures underlying the } \\
\text { unity of society? Such as Sunan Bonang in } \\
\text { Lasem. } \\
\text { Is there historical life principle in underlying the } \\
\text { unity of society? For example, in the Al Barakah } \\
\text { Mosque, the Army Strategic Command Boarding } \\
\text { Principle prioritizes unity over differences. } \\
\text { Are those still maintained? } \\
\text { How the momentum is preserved by the } \\
\text { generations afterward? Such as through } \\
\text { storytelling, building monuments, making } \\
\text { mottos, or through public activities. }\end{array}$ & $\begin{array}{l}\text { Nationalism is a } \\
\text { sense of brotherhood } \\
\text { "brotherhood or } \\
\text { sisterhood". } \\
\text { Although the people } \\
\text { are different but they } \\
\text { are brothers because } \\
\text { they live in the same } \\
\text { homeland. Different } \\
\text { communities but they } \\
\text { are brothers because } \\
\text { they speak the same } \\
\text { language and become } \\
\text { one bond for the } \\
\text { same nationality. }\end{array}$ \\
\hline
\end{tabular}




\begin{tabular}{|c|c|c|c|}
\hline 2 & Prejudice & $\begin{array}{l}\text { How is the prejudice towards people of other } \\
\text { religions? } \\
\text { Prejudice will emerge a keyword "our people, } \\
\text { they are not our people." In religious moderation } \\
\text { research, it is essential to discover whether there } \\
\text { is a classification su as "them" and "us" groups. } \\
\text { Is the boundary between "them and us" very } \\
\text { thick? What is the prejudice (their way of seeing } \\
\text { others) between all citizens of different religions } \\
\text { and cultures? }\end{array}$ & $\begin{array}{l}\text { This question is } \\
\text { related to the } \\
\text { indicators of } \\
\text { Nationalism and } \\
\text { Tolerance. } \\
\text { In Indonesia, } \\
\text { religious moderation } \\
\text { cannot be separated } \\
\text { from ethnicity. } \\
\text { Therefore, in a } \\
\text { research, it is } \\
\text { necessary to eximine } \\
\text { how is the prejudice } \\
\text { towards other } \\
\text { religions and } \\
\text { ethnicities? } \\
\text { Tolerance will be } \\
\text { established if there is } \\
\text { no prejudice among } \\
\text { different people. }\end{array}$ \\
\hline 3 & Truth Claim & $\begin{array}{l}\text { How to acknowledge that other people or ethnic } \\
\text { groups have their truths? } \\
\text { What is the regious foundation for them to accept } \\
\text { people of other religions? } \\
\text { How to accept houses of worship of other } \\
\text { religions? } \\
\text { How to view the different life practices of people } \\
\text { of other religions, in terms of religious practices } \\
\text { and food? }\end{array}$ & $\begin{array}{l}\text { The question } \\
\text { containing the } \\
\text { principle of equality, } \\
\text { "I have a truth claim, } \\
\text { yet accepting that } \\
\text { other people } \\
\text { embarace other } \\
\text { religions that } \\
\text { considered to be } \\
\text { accurate. This } \\
\text { question is related to } \\
\text { non-violence because } \\
\text { it tends to open up } \\
\text { space for discussion } \\
\text { without violence } \\
\text { when you see others } \\
\text { as having equality. } \\
\text { This question also } \\
\text { contains an indicator } \\
\text { of tolerance. }\end{array}$ \\
\hline
\end{tabular}




\begin{tabular}{|c|c|c|c|}
\hline 4 & Local Wisdom & $\begin{array}{l}\text { How do you resolve existing conflicts? } \\
\text { Is there a motto / quote created? } \\
\text { Are there methods based on local } \\
\text { culture/wisdom? }\end{array}$ & $\begin{array}{l}\text { This question } \\
\text { exploring the } \\
\text { dynamics of } \\
\text { interreligious/cultural } \\
\text { relations. The } \\
\text { examples could be } \\
\text { conflicts that had } \\
\text { been experienced and } \\
\text { how were they } \\
\text { resolved. Such as, in } \\
\text { Lasem they have a } \\
\text { tradition of } \\
\text { Jagongan. } \\
\text { This question } \\
\text { contains indicators of } \\
\text { religious moderation, } \\
\text { namely } \\
\text { accomodative } \\
\text { towards local culture } \\
\text { and non-violence. }\end{array}$ \\
\hline 5 & $\begin{array}{l}\text { Economic } \\
\text { Relations }\end{array}$ & $\begin{array}{l}\text { How is the economic life of society? } \\
\text { How are the economic relationships between } \\
\text { buyers and sellers? Is it limited to buying and } \\
\text { selling, or is there an ordinary conversation? } \\
\text { How is the relationship between an entrepreneur } \\
\text { and his / her employees/labor? Do entrepreneurs } \\
\text { consider their workers as objects of business so } \\
\text { that they are exploited and mistreated? } \\
\text { How does each party view the economy? Is it } \\
\text { positive or destroy each other? For example, in } \\
\text { Lasem, the entrepreneur considers the batik } \\
\text { makers as key figures in the hand-made batik } \\
\text { business, so that he/she perceive them as subjects } \\
\text { and pays them with a reasonable price. While in } \\
\text { other areas there is a streotype in economic } \\
\text { relations, where Chinese entrepreneurs are } \\
\text { labelled as stingy, and pribumi as lazy } \\
\text { employees. }\end{array}$ & $\begin{array}{l}\text { Experience in } \\
\text { economic relations is } \\
\text { very influential } \\
\text { in the life of religious } \\
\text { people. If the } \\
\text { relationship is } \\
\text { positive, the } \\
\text { storytelling creates a } \\
\text { positive image, but if } \\
\text { it is terrible, then } \\
\text { prejudice will spread } \\
\text { between the groups. }\end{array}$ \\
\hline
\end{tabular}

Religious moderation is a highest level of awareness. Where consciousness means a mental capability that provides humans the ability to understand reality and free will which enables various interpretations of reality (Takwin, 85). 


\section{Conclusion}

This research examines religious moderation which is contained RPJMN 2021-2024. The research question are, what is religious moderation and the difference with harmony? How to conduct research on religious moderation? This study finds that religious moderation is different from harmony because harmony is the result of religious moderation. Religious moderation is a paradigm of a just and balanced heart. Religious moderation is a path in the context of diversity that seeks to bridge differences. Research on religious moderation is carried out by examining the social cohesion history and its maintance, examining the prejudice towards other religious groups, examining the equality of truth claims on their respective religions, how local wisdom is created or maintained as a system for managing conflict, and how economic relations in society.

From this research I, as a Christian, learn how Muslims deal with diversity both externally and internally. Islam is diverse and is based on the principles of communalism because it is based on the concept of "Ummah", and it has faced diversity for centuries. As stated by M Natsir, "In the daily struggles of life, where differences cannot be reconciled, differences regarding understanding, charity, religion, and so on, a Muslim must not remain passive and drown and paralyzed his/her heart in seeing the confusion of these differences. Differences in worship and religion should not cause despair."

\section{References}

[1] Albert Sydney Hornby: Oxford Advanced Learners Dictionary of Current English: Oxford University Press (2015)

[2] Ali Nurdin \& Maulidatus Syahrotin, 2019, Model Moderasi Beragama Berbasis Pesantren Salaf, Jurnal Islamica, Vol. 14 No. 1 (2019): September.

[3] Armstrong, Karen, 1993 A History of God: The 4000-Year Quest of Judaism, Christianity and Islam. (A Borzoi Book.) New York.

[4] Budi Ayani, 2015: Islam Politik dalam Media Massa, IN RIGHT Jurnal Agama dan Hak Azazi Manusia Vol. 5, No. 1, November 2015.

[5] Busyro, 2019, Moderasi Islam (Wasathiyyah) di Tengah Pluralisme Agama Indonesia, Fuaduana: Jurnal Kajian Kegamaan dan Kemasyarakatan Vol. 03 No. 01, Januari-Juni 2019 IAIN Bukittinggi

[6] Bagus Takwin, (2005), Sebuah Sintesis Rasionalitas dan kehendak Bebas, Jalasutra, Yogyakarta. Departemen Pendidikan dan Kebudayaan, 1990: Kamus Besar Bahasa Indonesia (KBBI), Jakarata.

[7] Mir-Kasimov, Orkhan, ( 2014) Unity in Diversity;Mysticism, messianism and the Construction of Religious authority in Islam, Brill, Leiden Boston.

[8] Nashir, Haedar, Pidato Pengkuhuan Guru Besarnya dengan judul: Moderasi Indonesia dan Keindonesiaan Perspektif Sosiologi, UMY, 12 Des-2019

[9] Natsir, M (1969) Islam dan Kristen di Indonesia, c.v Bulan sabit Bandung

[10] Kamali, MohammadHashim; The Middle Path of Moderation in Islam: The Qur'ānic Princiiple

Wasatiyyah, Oxford University Press, Oxford, 2015.

[11] Leonard Swidler, 2014, Dialogue for Interreligious Understanding Strategies for The Transformation of Culture-Shaping Institutions, Palgrave Macmillan, New York

[12] Reid, Anthony, Revolusi Indonesia \& Sejumlah Isu Penting, Cetakan ke-1, terjemahan Tri Wibowo BS, Pernadamedia, Jakarta, 2018.

[13] Tim Penyusun Kementerian Agama RI, 2019: Moderasi Beragama, Puslitbang Kemenag RI.

[14] Craiutu , Aurelian, 2012, A Virtue for Courageous Minds Moderation in French Political Thought, 1748-1830 Princeton University Press

[15] Steven Shapin, Never Pure: Historical Studies of Science as if It Was Produced by People with Bodies, Situated in Time, Space, Culture, and Society, and Struggling for Credibility and Authority, second edition, Johns Hopkins University Press, 2010, 568 pages, page 245 (ISBN 978-0801894213). 